\title{
Molecular characterization of Rhodococcus equi isolates in equines
}

\author{
Rabyia Javed, A. K. Taku, R. K. Sharma and Gulzaar Ahmed Badroo
}

\author{
Department of Microbiology, Faculty of Veterinary Sciences \& Animal Husbandry, R.S. Pura, Sher-E-Kashmir University of \\ Agricultural Sciences and Technology, Jammu, Jammu and Kashmir, India. \\ Corresponding author: Rabyia Javed, e-mail: rabiajavedkhan@gmail.com, \\ AKT: aniltaku@gmail.com, RKS: rajni.psc@gmail.com, GAB: gulzardr@ymail.com \\ Received: 06-09-2016, Accepted: 07-12-2016, Published online: 05-01-2017
}

doi: 10.14202/vetworld.2017.6-10 How to cite this article: Javed R, Taku AK, Sharma RK, Badroo GA (2017) Molecular characterization of Rhodococcus equi isolates in equines, Veterinary World, 10(1): 6-10.

\begin{abstract}
Aim: The aim was to determine the occurrence of Rhodococcus equi in equines and their environment in Jammu (R.S. Pura, Katra), molecular characterization and to determine the antibiotic resistance pattern of $R$. equi.

Materials and Methods: A total of 96 nasopharyngeal swab samples were collected from equines. The organism was isolated on Columbia nalidixic acid agar containing 5\% sheep blood as well as on sheep blood agar and was later confirmed by cultural characteristics and biochemical tests. Molecular detection of $R$. equi isolates was done by $16 S r R N A$ gene amplification followed by virulence associated protein A (Vap A) gene amplification. Antibiogram was performed against five antibiotics, viz., amoxicillin, penicillin G, streptomycin, rifampicin, and methicillin.

Results: During the study, 9 R. equi isolates were identified on the basis of cultural and biochemical tests. In the polymerase chain reaction based detection, 3 among the 9 rhodococcal isolates were positive for species-specific $16 S$ rRNA gene and revealed amplicon of $450 \mathrm{bp}$ for confirmation of $16 \mathrm{~S} r R N A$ gene. None of the sample was found positive for Vap $A$ gene. In antibiogram, $R$. equi isolates were found sensitive for amoxicillin, while some isolates were also found resistant to the most conventional antibiotic penicillin $\mathrm{G}$.
\end{abstract}

Conclusion: From this study, it was concluded that $R$. equi infection is prevalent in equines in Jammu region of India and the indiscriminate use of the antibiotics is leading toward the development of resistant strains of $R$. equi.

Keywords: $16 S$ rRNA, polymerase chain reaction, Rhodococcus equi.

\section{Introduction}

For over 80 years, Rhodococcus equi has been recognized as a pulmonary pathogen of horses. The infection can spread from the lungs to other organs and joints when granulomatous foci in the lung open up, and infection of the gut lining causes diarrhea with an ulcerative enteritis and mucosal invasion of $R$. equi which is frequently observed in chronic disease. Immune complex deposition can cause polysynovitis which contribute to the development of uveitis, anemia or thrombocytopenia in infected foals. Occasionally, osteomyelitis and arthritis are also observed [1]. $R$. equi is Gram-positive, aerobic, nonmotile, nonsporulating, and metabolically diverse bacteria. The genus Rhodococcus (red pigmented cocci) belong to the phylogenetic group described as nocardia form actinomycetes. The infection causes subacute or chronic abscess or suppurative bronchopneumonia, ulcerative lymphangitis, enteritis, and causes zoonotic infection in foals aged 1-4 months [2,3].

Although infections can occur in healthy adult horses but are more common and severe in foals due

Copyright: Javed, et al. Open Access. This article is distributed under the terms of the Creative Commons Attribution 4.0 International License (http://creativecommons.org/licenses/by/4.0/), which permits unrestricted use, distribution, and reproduction in any medium, provided you give appropriate credit to the original author(s) and the source, provide a link to the Creative Commons license, and indicate if changes were made. The Creative Commons Public Domain Dedication waiver (http://creativecommons.org/ publicdomain/zero/1.0/) applies to the data made available in this article, unless otherwise stated. to their immune compromised immunity. It has been found that only a small proportion of all $R$. equi in soil are able to cause the infection and only $R$. equi carrying virulence plasmids can cause disease in foals [4].

In some strains of $R$. equi, the presence of a plasmid encoding a $15-17 \mathrm{kDa}$ protein called virulence associated protein $\mathrm{A}(\operatorname{Vap} A)$ is known to be responsible for virulence [5]. In $85 \%$ of the cases, presence of Vap A virulence plasmid has been associated with $R$. equi infection in foals for the last couple of decades [6]. Experiments with the presence of the Vap $A$ - expressing plasmid in $R$. equi showed an increase in the percentage of killed macrophages in a standard assay using trypan blue by roughly $20-70 \%$ in comparison with its cured equivalent strain.

The present investigation was undertaken to study the molecular diagnosis of $R$. equi including the therapeutics based on antimicrobial sensitivity tests.

\section{Materials and Methods}

\section{Ethical approval}

The approval from the Institutional Animal Ethics Committee to carry out this study was not required as no invasive technique was used. Nasal swab samples were being collected from clinically affected animals and healthy animals for this study as per standard collection procedure.

\section{Sample collection}

Total 96 nasopharyngeal Swabs samples (both clinically affected and apparently healthy animals) 
were collected from equines and immediately transported to the laboratory on ice for further processing. The laboratory work was conducted in the Division of Veterinary Microbiology and Immunology, Faculty of Veterinary Sciences and Animal Husbandry, SherE-Kashmir University of Agricultural Sciences and Technology-Jammu, R.S Pura, Jammu, Jammu and Kashmir, India.

\section{Isolation and identification of bacteria}

The nasal samples were inoculated on Columbia colistin nalidixic agar with 5\% sheep blood agar and sheep blood agar and incubated aerobically at $37^{\circ} \mathrm{C}$ for $48 \mathrm{~h}$ for the isolation of Rhodococcal isolates. The bacterial isolates which showed small smooth shiny and nonhemolytic colonies after $24 \mathrm{~h}$ incubation but became larger, mucoid and salmon-pink in color with age were selected for further processing. Initial confirmation of the isolates as $R$. equi was done by demonstration of the typical cellular morphology in Gram-stained smears. All the nine isolates of $R$. equi obtained during the study were characterized biochemically by various standard biochemical tests, viz., catalase, oxidase, Christein-Atkin-Munch-Peterson (CAMP) test using Staphylococcus aureus, esculin hydrolysis, nitrate reduction test, urease test, and sugar fermentation test. The results of the biochemical tests for $R$. equi isolates are shown in Table-1.

\section{Antibiogram}

All the isolates of $R$. equi were subjected to antibiotic sensitivity test by disc diffusion method using five antimicrobials amoxicillin $-30 \mathrm{mcg}$, penicillin $\mathrm{G}-25$ units, amikacin $-30 \mathrm{mcg}$, streptomycin $-10 \mathrm{mcg}$, and methicillin - $5 \mathrm{mcg}$ [7].

\section{Molecular identification of isolates by polymerase chain reaction (PCR) \\ $D N A$ extraction}

The DNA template was extracted from purified bacterial colonies using snap and chill method. The DNA samples were further stored at $-20^{\circ} \mathrm{C}$ till further use.

Table-1: Biochemical tests for characterization of $R$. equi.

\begin{tabular}{lcc}
\hline Test & Positive & Negative \\
\hline Catalase test & 9 & 0 \\
Oxidase test & 0 & 9 \\
CAMP test & 3 & 6 \\
Esculin hydrolysis & 0 & 9 \\
Nitrate reduction test & 9 & 0 \\
Urease test & 9 & 0 \\
Glucose & 0 & 9 \\
Maltose & 0 & 9 \\
Sucrose & 0 & 9 \\
\hline
\end{tabular}

CAMP $=$ Christein-Atkin-Munch-Peterson
Species-specific $16 S$ rRNA gene was amplified by PCR with slight modifications [8]. PCR was carried out in a final reaction volume of $25 \mu 1$ using $0.2 \mathrm{ml}$ thin wall sterile and nuclease free PCR tubes.

\section{PCR amplification}

The PCR mixture contained a final concentration of $3.50 \mathrm{mM} \mathrm{MgCl}, 0.2 \mathrm{mM}$ concentrations of each deoxyribonucleoside triphosphates (dNTPs), $3.0 \mu 1$ of $\times 10$ PCR buffer, $1.0 \mu \mathrm{M}$ of forward and reverse primers, $3.0 \mu$ template DNA, and $1.0 \mathrm{U}$ of taq DNA Polymerase (Promega limited, USA). The amplification cycle consisted of initial denaturation at $94^{\circ} \mathrm{C}$ for 5 min, followed by 35 cycles, each consisting of initial denaturation at $94^{\circ} \mathrm{C}$ for $30 \mathrm{~s}$, annealing at $52^{\circ} \mathrm{C}$ for $30 \mathrm{~s}$ and extension at $72^{\circ} \mathrm{C}$ for $1 \mathrm{~min}$ which was followed by final extension at $72^{\circ} \mathrm{C}$ for $10 \mathrm{~min}$. The sequence of forward and reverse primers used in the study is given in Table-2 with the predicted size of the PCR amplicon.

\section{PCR-based detection of $R$. equi using Vap A gene}

Vap $A$ gene was amplified by PCR with slight modifications. PCR was carried out in a final reaction volume of $25 \mu 1$ using $0.2 \mathrm{ml}$ with final concentration of $3.50 \mathrm{mM} \mathrm{MgCl}, 0.2 \mathrm{mM}$ concentrations of each dNTPs and $2.5 \mu 1$ of $\times 10$ PCR buffer [9]. The amplification cycle consisted of initial denaturation at $94^{\circ} \mathrm{C}$ for $2 \mathrm{~min}$, followed by 40 cycles, each consisting of initial denaturation at $94^{\circ} \mathrm{C}$ for $1.5 \mathrm{~min}$, annealing at $57^{\circ} \mathrm{C}$ for $1 \mathrm{~min}$ and extension at $72^{\circ} \mathrm{C}$ for 2 min which was followed by final extension at $72^{\circ} \mathrm{C}$ for $10 \mathrm{~min}$. Primer sequences used in the study and predicted size of the PCR amplicon is presented in Table-3.

\section{Results and Discussion}

In this study, a total of nine isolates were recovered as $R$. equi on the basis of morphology, colony characteristics, and biochemical properties as described earlier. Six out of 9 samples were found positive for CAMP test as shown in Table-1. CAMP test shown as spade shape hemolysis on blood agar (Figure-1).

The growth of $R$. equi on Columbia nalidixic agar with 5\% sheep blood revealed small, smooth, shiny, and nonhemolytic colonies. After $24 \mathrm{~h}$ of incubation colonies became larger, mucoid and salmon - pink in color (Figure-2). The isolates of $R$. equi appeared as Gram-positive coccobacillary in Gramstained smears. Out of nine, three R. equi isolates (two were from Katra and one from R.S. Pura [Table-4]) were confirmed positive as they revealed an amplicon of $450 \mathrm{bp}$ (Figure-3) in $16 \mathrm{~S} r R N A$ amplification. It had also been reported earlier that the detection rate

Table-2: List of oligonucleotide primers for detection of species specific $16 S$ rRNA gene.

\begin{tabular}{llc}
\hline Primer name & Nucleotide sequence & Product size (bp) \\
\hline Forward primer & $5^{\prime}$-GGTCTAATACCGGATATGAGCTCCTGTC 3' & 450 \\
Reverse primer & $5^{\prime}$-CGCAAGCTTGGGGTTGAGCCCAA 3' & \\
\hline
\end{tabular}


of $R$. equi by $16 S$ rRNA PCR was $10.63 \%$ compared to $8.5 \%$ by culture $[10,11]$. However, it is recognized that PCR-based detection of $R$. equi from clinical

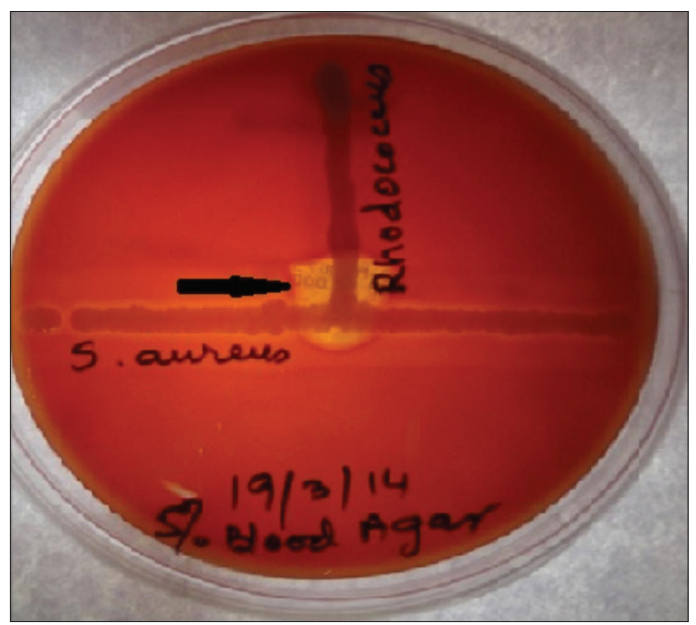

Figure-1: Rhodococcus equi showing spade shaped hemolysis on blood agar.

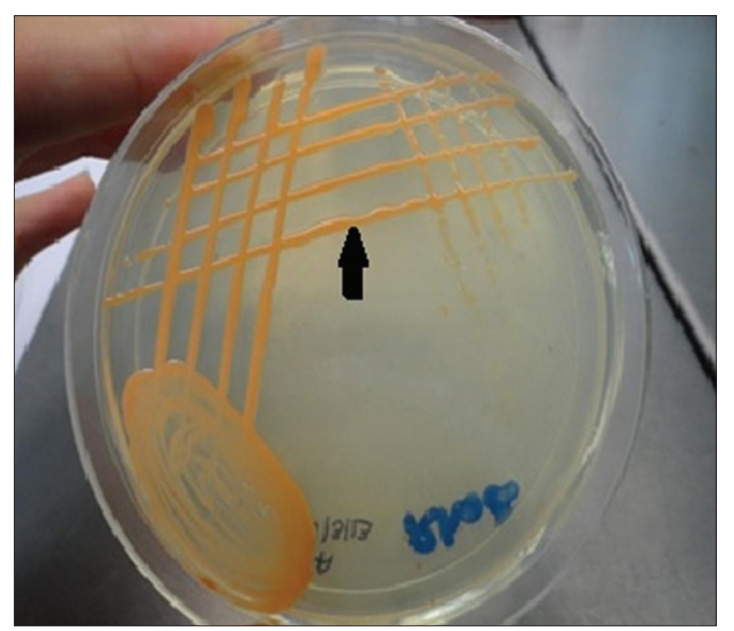

Figure-2: Salmon pink colored colonies of Rhodoccus equi on nutrient agar.

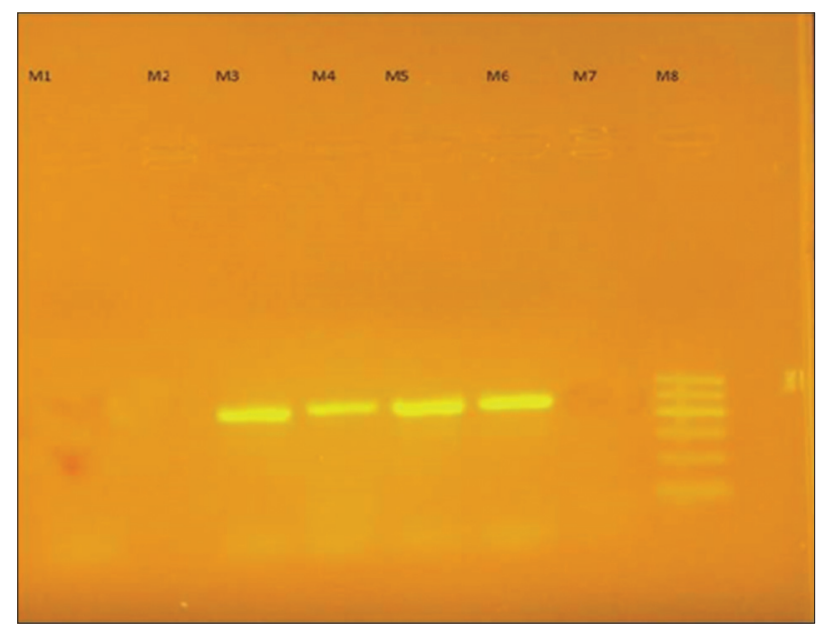

Figure-3: Amplified product of species specific $16 S$ rRNA polymerase chain reaction (PCR) of Rhodococcus equi at 450 bp. Lane M1, M2, M7 - Negative sample, Lane M3, M4, M5 - Amplified product of 165 rRNA PCR of $R$. equi at 450 bp, Lane M6 - Positive control, Lane M8 - Molecular weight marker of $500 \mathrm{bp}$ (Himedia, India). samples is more sensitive than microbiological culture characterization [12]. PCR-based detection of R. equi is given in Table-4.

In this study, the prevalence of $R$. equi recorded is less than that in an earlier report [13]. The low recovery rate of $R$. equi can be attributed to the fact that we did not use the invasive collection method of tracheobronchial aspiration which is regarded as the best method for definitive diagnosis of $R$. equi infection [14]. This method was not selected due to technical difficulty, reluctance by owners and associated life-threatening consequences. Another probable reason is the sporadic nature of the disease [15].

The virulence-associated antigens (Vap-A) and plasmids are used as epidemiological markers for $R$. equi virulence in foals [16]. In this study, none was found positive on PCR-based detection of $R$. equi using $\operatorname{Vap} A$ gene. However, observations were made, where a number of plasmid less $R$. equi isolates were found to be associated with clinical cases of foal pneumonia [17]. Therefore, it may be anticipated that occurrence of virulent plasmid may not entail the disease causing ability of $R$. equi rather it may intensify the pathogenic behavior of the organism and aggravate the disease prognosis. However, in one of the studies, it was found that environmental isolates are Vap A negative [18].

In the present study besides the recovery of target organisms, a variety of other bacterial isolates were obtained which were identified by conventional culture methods and by a set of standard biochemical tests. They were identified as S. aureus, Pseudomonas, Proteus, Enterococcus, and Streptococcus pluranimalium.

The antibiotic sensitivity assay for $R$. equi revealed that amoxicillin was the most effective followed by streptomycin and rifampicin. Results further revealed that resistance was highest for penicillin G. Results of antibiotic sensitivity assay for $R$. equi are presented in Table-5. Sensitivity patterns in most of the isolates, even within subspecies, varied remarkably. Earlier reports of the antimicrobial sensitivity on

Table-3: List of oligonucleotide primers for Vap A gene.

\begin{tabular}{llc}
\hline Primer name & Nucleotide sequence & $\begin{array}{c}\text { Product } \\
\text { size (bp) }\end{array}$ \\
\hline Forward primer & 5'-GACTCTTCACAAGACGGT-3' & 563 \\
Reverse primer & 5'-TAGGCGTTGTGCCAGCTA-3' & \\
\hline
\end{tabular}

Table-4: 16S rRNA gene showing result of PCR of $R$. equi from equines.

\begin{tabular}{lcc}
\hline Region & $\begin{array}{c}\text { Number of isolates } \\
\text { subjected to PCR }\end{array}$ & $\begin{array}{c}\text { Positive for 16S rRNA } \\
\text { gene }\end{array}$ \\
\hline R.S. Pura & 4 & 1 \\
Katra & 5 & 2 \\
Total & 9 & 3 \\
\hline
\end{tabular}

$R$. equi=Rhodococcus equi, $\mathrm{PCR}=$ Polymerase chain reaction 
Table-5: Results of antibiogram for $R$. equi.

\begin{tabular}{lcccccc}
\hline Antibiotic & $\begin{array}{c}\text { Number of } \\
\text { sensitive isolates }\end{array}$ & $\begin{array}{c}\text { Number of } \\
\text { resistant } \\
\text { isolates }\end{array}$ & $\begin{array}{c}\text { Number of } \\
\text { intermediate } \\
\text { isolates }\end{array}$ & \% Sensitive & \% Resistant & \% Intermediate \\
\hline Amoxicillin & 3 & 0 & 0 & 100 & 0 & 0 \\
Streptomycin & 2 & 0 & 1 & 66.66 & 0 & 33.33 \\
Penicillin & 0 & 3 & 0 & 0 & 100 & 0 \\
Methicillin & 1 & 2 & 0 & 33.33 & 66.66 & 0 \\
Rifampicin & 2 & 0 & 1 & 66.66 & 0 & 33.33 \\
\hline
\end{tabular}

$R$. equi=Rhodococcus equi

streptococcal isolates also indicated a wide variation in the sensitivity to various antibiotics used [19-21]. Although we did not find any multidrug-resistant strains, there is a need for the proper judicious use of antimicrobial agents for effective treatment and prevention of emergence of resistant strains. Resistance of the some of the isolates to a number of antibiotics seems to be outcome of indiscriminate use of those antibiotics in the field. The best therapeutic approach is a two-step approach. In the first step, combination of bactericidal drugs such as vancomycin plus imipenem is used to kill extracellular organisms and in the second step; a combination of drugs that penetrate the cell such as erythromycin plus rifampicin is administered for a period of at least 2 months [22]. The antibiogram study indicates that amoxicillin and streptomycin are the effective drugs used against bacterial pathogens. However, the emergence of drug resistance bacteria can be alarming which needs close and repeated vigilance. The indiscriminate use of antibiotics should be avoided. The different combination of antibiotics should be changed from time to time.

$R$. equi is an important pathogen which results in severe bronchopulmonary pneumonia not only in animals but also in humans. Every year, the state of Jammu and Kashmir is visited by thousands of tourists and pilgrims who use equines for recreational and religious purposes. During this time, they come in close contact with these equines and are at risk of getting infections from them and subsequently spreading them to other parts of the country. High infection rates of this pathogen have been associated with immunocompromised individuals, particularly AIDS patients [15].

\section{Conclusion}

From this study, it was concluded that $R$. equi infection is prevalent in equine (Jammu region) in India, and as such, extensive studies with clinical samples from $R$. equi-infected and non-infected foals, adult equines, and environmental samples from various geographical locations are required for the molecular epidemiological analysis of $R$. equi. It was also found that indiscriminate use of the antibiotics is leading toward the development of resistant strains of $R$. equi.

\section{Authors' Contributions}

$\mathrm{RJ}$ and AKT designed the study. Laboratory work was done by RJ, GAB,RKS and AKT. All the authors participated in data analysis, while RJ drafted and revised the manuscript. All authors read and approved the final manuscript.

\section{Acknowledgments}

The authors are thankful to Faculty of Veterinary Sciences and Animal Husbandry R.S. Pura, Jammu, and the funding agency Veterinary Type Culture Centre (ICAR), National Research Centre on Equines, Sirsa Road, Hisar, Haryana, India for providing necessary research facilities.

\section{Competing Interests}

The authors declare that they have no competing interests.

\section{References}

1. Khurana, S.K., Singha, H., Malik, P., Gulati, B.R. and Singh, R.K. (2015) Molecular characterization of clinical isolates of Rhodococcus equi with PCR assay based on virulence plasmid marker. Indian J. Anim. Sci., 85(10): 1063-1066.

2. Giguere, S., Hondalus, M.K., Yager, J.A., Darrah, P., Mosser, D.M. and Prescott, J.F. (1999) Role of the 85-kilobase plasmid and plasmid-encoded virulence-associated protein A in intracellular survival and virulence of Rhodococcus. Infect. Immun., 67(7): 3548-3557.

3. Meijer, W.G. and Prescott, J.F. (2004) Rhodococcus equi. Vet. Res., 35: 383-396.

4. Muscatello, G., Anderson, G.A., Gilkerson, J.R. and Browning, G.F. (2006) Associations between the ecology of virulent Rhodococcus equi and the epidemiology of R. equi pneumonia on Australian thoroughbred farms. Appl. Environ. Microbiol., 72: 6152-6160.

5. Takai, S. (1991) Association between a large plasmid and 15 to 17-kilodalton antigens in virulent Rhodococcus. Infect. Immun., 59: 4056-4060.

6. Rodriguez-Lazaro, D., Lewis, D.A., Ocampo-Sosa, A.A., Fogarty, U., Makrai, L., Navas, J., Scortti, M., Hernandez, M. and Vazquez-Boland, J.A. (2006) Internally controlled realtime PCR method for quantitative species-specific detection and vap $A$ genotyping of Rhodococcus. Appl. Environ. Microbiol., 72(6): 4256-4263.

7. Baeur, A.W., Kirby, W.M.M., Sherris, J.C. and Truck, N. (1996) Antibiotic susceptibility testing by a standardized single disc method. Am. J. Clin. Pathol., 45: 493-496.

8. Bell, K.S., Philip, J.C., Christofi, N. and Aw, D.W.J. (1996) Identification of Rhodococcus equi using the polymerase chain reaction. Lett. Appl. Microbiol., 23: 72-74.

9. Muscatello, G., Haites, R.E., Browning, G.F. and Angela, P.B. (1997) Prevalence of the virulence-associated gene of Rhodococcus equi in isolates from infected foals. J. Clin. Microbiol., 35(6), 1642-1644.

10. Tkachuksaad, O. and Prescott, J. (1991) Rhodococcus equi plasmids-isolation and partial characterisation. J. Clin. 
Microbiol., 29(12): 2696-2700.

11. Anzai, T., Wada, R., Nakanishi, A., Kamada, M., Takai, S., Shindo, Y. and Tsubaki, S. (1997) Comparison of tracheal aspiration with other tests for diagnosis of Rhodococcus equi pneumonia in foals. Vet. Microbiol., 56: 335-345.

12. Vivrette, S.L., Sellon, D.C. and Gibbons, D.S. (2000) Clinical application of a polymerase chain reaction assay in the diagnosis of pneumonia caused by Rhodococcus equi in a horse. J. Am. Vet. Med. Assoc., 217: 1348-1350.

13. Khurana, S.K., Malik, P., Virmani, N. and Singh, B.R. (2009) Prevalence of Rhodococcus equi infection in foals. Indian J. Vet. Res., 18: 20-22.

14. Sweeney, C.R., Sweeney, R.W. and Divers, T.J. (1987) Rhodococcus equi pneumonia in 48 foals: Response to antimicrobial therapy. Vet. Microbiol., 14: 329-336.

15. Prescott, J.F., Wilcock, B.P., Carman, P.S. and Hoffman, A.M. (1991) Sporadice, severe broncho interstitial pneumonia of foals. Can. Vet. J., 32(7): 421-425.

16. Cohen, N.D., O'Connor, M.S., Chaffin, M.K. and Martens, R.J. (2005) Farm characteristics and management practices associated with development of Rhodococcus equi pneumonia in foals. J. Am. Vet. Med. Assoc., 226: 404-413.
17. Morton, A.C., Begg, A.P., Anderson, G.A., Takai, S., Lammler, C. and Browning, G.F. (2001) Epidemiology of Rhodococcus equi strains on thoroughbred horse farms. Appl. Environ. Microbiol., 67(5): 2167-2175.

18. Krewer, C.D.C., Spricigo, D.A., Botton, S.D.A., Da-Costa, M.M., Schrank, I. and De-Vargas, A.C. (2008) Molecular characterization of Rhodococcus equi isolates of horse breeding farms from an endemic region in South of Brazil by multiplex PCR. Braz. J. Microbiol., 39: 188-193.

19. Narwal, P.S., Monga, D.P. and Bhargava, D.N. (1994) Microbiological studies of reproductive disorder in equines. Indian J. Anim. Sci., 64: 51-55.

20. Welsh, R.D. (1984) The significance of Streptococcus zooepidemicus in the horse. Equine Pract., 6: 6-16.

21. Uppal, P.K., Singh, B.K., Yadav, M.P. and Ghei, J.C. (1994) Identification and antibiogram of bacterial flora associated with reproductive disorders of mares. Int. J. Anim. Sci., 9: 57-58.

22. Gabriels, P., Joosen, H., Put, E., Verhaegen, J., Magerman, K. and Cartuyvels, R. (2006) Recurrent Rhodococcus infection with fatal outcome in an immune competent patient. Eur. J. Clin. Microbiol. Infect. Dis., 25(1): 46-48.

\section{$* * * * * * * *$}

